\title{
Life satisfaction is the most significant determinant of quality of life in the elderly
}

\author{
Thania Vinsalia* and Yvonne Suzy Handajani**@
}

\begin{abstract}
*Center of Health Research, School of Medicine and Health Sciences, Atma Jaya Catholic University of Indonesia, Jakarta, Indonesia **Department of Public Health and Nutrition,

School of Medicine and Health Sciences, Atma Jaya Catholic University of Indonesia,

Jakarta, Indonesia

Correspondence:

${ }^{\circledR}$ Yvonne Suzy Handajani

School of Medicine \& Health

Sciences, Atma Jaya Catholic

University of Indonesia,

J1. Pluit Selatan Raya No.19,

Jakarta Utara, 14440

Phone: +628161353738

Email: yvonne.hand@atmajaya.ac.id ORCID ID: 0000-0002-8245-9354

Date of first submission, October 1, 2020

Date of final revised submission,

January 2, 2021

\section{BACKGROUND}

Quality of life tends to decrease as age increases. This study aimed to determine the most significant risk factors (family support, spirituality, and life satisfaction) for the elderly's quality of life.

\section{METHODS}

This was a cross-sectional study of 101 subjects aged $\geq 60$ years in West Jakarta. The variables were assessed using the World Health Organization Quality of Life-BREF (WHOQOL-BREF), Family Support, Daily Spiritual Experience Scale (DSES), and the Satisfaction with Life Scale (SWLS) instruments. Multivariate logistic regression was used to analyze the association between quality of life and its determinant factors.

\section{RESULTS}

Based on sociodemographic characteristics, the respondents were mostly women $(66.3 \%)$, had more than nine years of education $(79.2 \%)$, and were married (56.4\%). The analysis showed that life satisfaction was significantly associated with overall quality of life $(\mathrm{OR}=9.71 ; 95 \% \mathrm{CI}: 2.04-46.26 ; \mathrm{p}=0.004)$ and general health $(\mathrm{OR}=7.52 ; 95 \% \mathrm{CI}: 1.70-33.25 ; \mathrm{p}=0.008)$. Life satisfaction was also a risk factor for the environmental domain $(\mathrm{OR}=36.02 ; 95 \% \mathrm{CI}: 5.07-$ 255.82; $<<0.001)$. Furthermore, spirituality was found to be a risk factor for the physical health domain $(\mathrm{OR}=4.18 ; 95 \% \mathrm{CI}: 1.51-11.59 ; \mathrm{p}=0.006)$, psychological domain $(\mathrm{OR}=6.67 ; 95 \% \mathrm{CI}: 2.4-17.86 ; \mathrm{p}<0.001)$, and environmental domain $(\mathrm{OR}=11.46 ; 95 \% \mathrm{CI}: 3.10-42.37$; $\mathrm{p}<0.001)$.
\end{abstract}

Date of acceptance, January 5, 2021

This open access article is distributed under a Creative Commons AttributionNon Commercial-Share Alike 4.0 International License

Cite this article as: Vinsalia T, Handajani YS. Life satisfaction is the most significant determinant of quality of life in the elderly Univ Med 2021;40:14-21. doi: 10.18051/UnivMed.2021.v40.14-21

\section{CONCLUSION}

Life satisfaction plays a significant role in increasing the environmental domain of quality of life, the overall quality of life, and general health among the elderly. Awareness of these factors can assist providers in identifying people at risk and guide new intervention programs to improve care for these invaluable elderly of our communities.

Keywords : Elderly, life satisfaction, spirituality, family support, quality of life 


\section{INTRODUCTION}

The elderly population in Indonesia and globally has increased significantly. There are an estimated 962 million people aged 60 years or over worldwide. According to the United Nations (UN), since 2015, Asia and Indonesia have entered the era of aging population because the percentage of the population aged 60 or over has exceeded 7\% ${ }^{(1)}$ In 2018 , the percentage of the elderly population in Indonesia was 9.27\% (24.49 million). The Indonesian Central Statistics Agency (Badan Pusat Statistik, BPS) projected that by 2045 , this rate will rise to $20 \%$ or approximately 63.31 million people..$^{(2)}$

As age increases, the quality of life tends to decrease. Lack of social interactions, poor health condition, decreased physical and mental functions lead to emotional disturbances that affect the quality of life. ${ }^{(3)}$ Kaur et al. ${ }^{(4)}$ stated that support from family relations contributes to a higher ability of the elderly to cope with changes in health, social activities, and more. It provides individual emotional, social, and economic support. Family support increases not only the quality of life of the elderly, but also the quality of life of the family itself. ${ }^{(5)}$

Spiritual needs that are not fulfilled are often associated with a poor quality of life. GonzálesCelis et al. ${ }^{(6)}$ compared levels of quality of life in each of the six domains of the WHOQOL-100 questionnaire and found that spirituality had the highest score. Besides that, elderly with high spiritual level tend not to have depression. Elderly without depressive symptoms have a better quality of life. High spirituality leads older people to think more positively and therefore to have good health. ${ }^{(7,8)}$ Poor et al. ${ }^{(9)}$ also stated that older people with stronger religious beliefs have a greater life expectancy. However, a study by Jafaripoor et al. ${ }^{(10)}$ showed a contradictive result. Life satisfaction also plays a role as an indicator of the quality of life. Physical and mental health significantly influence life satisfaction, which eventually affects the quality of life of the elderly. ${ }^{(11)}$ However, a study by Kiarsipour et al. ${ }^{(12)}$ in Iranian older adults showed a contradictory result where they found a low life satisfaction level due to the negative aging perception.

There is a positive association of religiosity and spirituality with quality of life. . $^{(13)}$ The empirical evidence concerning the relationship of quality of life with religiosity and spirituality essentially focuses on health, with few studies seeking to analyze this association by incorporating the multidimensional character of quality of life into their empirical analyses. A study conducted in nursing homes has reported a positive correlation between social support received from the family and quality of life..$^{(14)}$

Most studies only analyze the relationship between family support or spirituality or life satisfaction with the quality in the elderly. The difference between the present study with previous studies was that in our study, all three risk factors (family support, spirituality, and life satisfaction) were the independent variables on the quality of life, and we assessed the most dominant factors affecting the quality of life. This study aimed to determine the most significant risk factors (family support, spirituality, and life satisfaction) of the elderly's quality of life.

\section{METHODS}

\section{Research design}

A study of cross-sectional design was conducted in the Pusat Santunan dalam Keluarga (PUSAKA) of Meruya Ilir (a community-based home care center) in West Jakarta, Indonesia, between October 27 $7^{\text {th }}, 2018$ until November $24^{\text {th }}, 2018$.

\section{Research subjects}

The sample size determination was done by using the Lemeshow formula with $\alpha=0.05$. The prevalence of elderly with poor quality of life was $23.6 \%,{ }^{(15)}$ which obtained 70 respondents. To anticipate dropouts, $10 \%$ of the total sample was added to obtain 77 respondents. Simple random sampling was done for the sampling selection. 
From several community-based home care facilities in 5 areas of Jakarta, West Jakarta was randomly selected. There are several communitybased home care facilities in West Jakarta, and PUSAKA Meruya Ilir was randomly selected. All of the 267 elderly living in PUSAKA Meruya Ilir were listed and numbered. From these, 101 participants were chosen using SPSS random sampling.

This study's inclusion criteria were subjects aged 60 years and older residing in PUSAKA Meruya Ilir who were willing to become respondents and agreed to sign informed consent. Subjects who had hearing and communication impairments were excluded from the study.

\section{Measurements}

Spirituality was assessed using the present authors' modification of the Daily Spiritual Experience Scale (DSES), consisting of 15 items with a 6-scale scoring system, with 1 being almost all day long and 6 being never or seldom. A total score between $15-40$ is considered high, and 4188 is considered low. Lower scores indicate higher frequency of spiritual experiences. ${ }^{(16)}$ The DSES questionnaire has high reliability with a Cronbach's Alpha value of $\geq 0.9$. $^{(17,18)}$

The assessment of family support was done by using the family support scale questionnaire. There are 13 questions which are rated on a fivepoint scale, with 1 being "I disagree a lot" and 5 "I agree a lot". ${ }^{19)}$ Family support is considered high if the total score is $>37 .^{(20)}$ This instrument has proven to be reliable with a Cronbach's Alpha value of $0.820 .^{(19)}$

Life satisfaction was assessed using the Satisfaction with Life Scale (SWLS) consisting of 5 questions representing the following five components: the desire to change a life, satisfaction with the present life, with life in the past and future, and individual's appraisal of his life. It uses a 7-scale scoring system, with 1 being 'strongly disagree' with the statement and 7 being 'strongly agree' with the statement. A total score between 20-35 is considered satisfactory, and a score of $\leq 19$ is considered unsatisfactory. ${ }^{(21,22)}$
The Cronbach's Alpha value for SWLS ranges between $0.78-0.83 .^{(23)}$

Lastly, the quality of life was assessed using the 26-item World Health Organization Quality of Life - BREF (WHOQOL - BREF) instrument. The four domains were distributed into 24 questions, while the other two questions were about the overall quality of life and general health. Each question is assigned a score of 1 to 5 , and higher scores represent a better quality of life. A total score of 60 is considered good and a score of $<60$ is considered moderate-poor. ${ }^{(24)}$ The four quality of life domains have good reliability, with Cronbach's Alpha value ranging between $0.41-0.77 .^{(15)}$

\section{Data analysis}

Univariate analysis was performed to determine the respondents' characteristics and summarize the distribution of variables. Multivariate-adjusted odds ratios (ORs) with 95\% confidence intervals (CIs) were used to determine the association between quality of life and determinant factors. By using multiple logistic regression analysis, the results were automatically adjusted. ${ }^{(25)}$ The data was analyzed using SPSS version 23 . A p-value $<0.05$ was considered statistically significant.

\section{Ethical clearance}

This study obtained ethical clearance with the following reference number: FKIK UNIKA Atma Jaya No.13/12/KEP-FKUAJ/2018.

\section{RESULTS}

The majority of subjects in this study were 65 years old and over $(80.2 \%)$, female $(66.3 \%)$, had more than nine years of education $(79.2 \%)$, and were married $(56.4 \%)$. Most of the respondents had high family support (73.3\%), high spirituality level (75.2\%), and high life satisfaction $(88.1 \%)$ (Table 1$)$. As an overview of the quality of life based on the overall quality of life and general health, most subjects had a good overall quality of life $(81.2 \%)$ and $64.4 \%$ had excellent general health. 
Table 1. Distribution of sociodemographic characteristics and variables $(n=101)$

\begin{tabular}{ll}
\hline Variables & n (\%) \\
\hline Age (years) & \\
$\quad<65$ & $20(19.8)$ \\
$\geq 65$ & $81(80.2)$ \\
Sex & \\
$\quad$ Male & $34(33.7)$ \\
Female & $67(66.3)$ \\
Education & \\
$\quad \leq 9$ years & $21(20.8)$ \\
$>9$ years & $80(79.2)$ \\
Marital status & \\
$\quad$ Single & $7(6.9)$ \\
$\quad$ Married & $57(56.4)$ \\
Divorced & $37(36.6)$ \\
Family support & \\
$\quad$ Low & $27(26.7)$ \\
High & $74(73.3)$ \\
Spirituality & \\
Low & $25(24.8)$ \\
High & $76(75.2)$ \\
Life satisfaction & \\
$\quad$ Not satisfied & $12(11.9)$ \\
$\quad$ Satisfied & $89(88.1)$ \\
Overall quality of life & \\
$\quad$ Good & $82(81.2)$ \\
Moderate-Poor & $19(18.8)$ \\
General health & \\
Good & $65(64.4)$ \\
Moderate-Poor & $36(35.6)$ \\
\hline
\end{tabular}

Results from the analysis showed that sex was significantly associated with general health $(\mathrm{OR}=5.30 ; 95 \% \mathrm{CI}=1.72-16.36 ; \mathrm{p}=0.004)$. Subjects with low life satisfaction has a risk factor for poor overall quality of life $(\mathrm{OR}=9.71 ; 95 \%$ $\mathrm{CI}=2.04-46.26 ; \mathrm{p}=0.004)$ and general health $(\mathrm{OR}=7.52 ; 95 \% \mathrm{CI}=1.70-33.25 ; \mathrm{p}=0.008)$. The elderly with low life satisfaction had a nine times higher risk for low quality of life and seven times higher risk for low general health. Low spiritual level was also a risk factor for the overall quality of life $(\mathrm{OR}=5.84 ; 95 \% \mathrm{CI}=1.77-19.23 ; \mathrm{p}=$ 0.004) (Table 2). Those with low spiritual level also had a six times higher risk for a low quality of life. Those with low spiritual level also had a six times higher risk for a low quality of life.

Table 3 showed that sex had significant associations with both the social interactions domain $(\mathrm{OR}=4.77 ; 95 \% \mathrm{CI}=1.87-12.16$; $\mathrm{p}=$ $0.001)$ and the environmental domain $(\mathrm{OR}=5.51$; $95 \% \mathrm{CI}=1.20-25.24 ; \mathrm{p}=0.028)$. Spirituality was a risk factor for the physical health domain $(\mathrm{OR}=4.18 ; 95 \% \mathrm{CI}=1.51-11.59 ; \mathrm{p}=0.006$, psychological domain $(\mathrm{OR}=6.67 ; 95 \% \mathrm{CI}=2.49$ - 17.86; $\mathrm{p}<0.001)$, social interactions domain $(\mathrm{OR}=3.71 ; 95 \% \mathrm{CI}=1.07-12.82 ; \mathrm{p}=0.038)$, and environmental domain $(\mathrm{OR}=11.46 ; 95 \% \mathrm{CI}=3.10$ $-42.37 ; p<0.001)$. Furthermore, life satisfaction was also a risk factor of the environmental domain $(\mathrm{OR}=36.02 ; 95 \% \mathrm{CI}=5.07-255.82 ; \mathrm{p}<0.001)$.

\section{DISCUSSION}

Sex was significantly associated with general health, social interactions domain, and environmental domain. Many studies (26-28) showed similar results. Studies conducted in Kuala Lumpur ${ }^{(26)}$ and the Netherlands ${ }^{(28)}$ also showed that sex had a significant association with social interactions and environmental domains. Women rated the social domain of quality of life higher

Table 2. Multivariate logistic regression for factors related to overall quality of life and general health

\begin{tabular}{lcccccc}
\hline \multirow{2}{*}{ Factors } & \multicolumn{3}{c}{ Overall quality of life } & \multicolumn{2}{c}{ General health } \\
\cline { 2 - 7 } & OR & $\mathbf{9 5} \%$ C.I. & p value & OR & $\mathbf{9 5 \% ~ \% . I . ~}$ & p value \\
\hline Age & 0.95 & $0.83-1.07$ & 0.382 & 1.01 & $0.92-1.10$ & 0.892 \\
Sex & 1.27 & $0.33-4.95$ & 0.730 & 5.30 & $1.72-16.36$ & $0.004 *$ \\
Education & 0.70 & $0.42-1.18$ & 0.182 & 0.76 & $0.51-1.13$ & 0.171 \\
Marital status & 0.37 & $0.13-1.05$ & 0.061 & 0.81 & $0.38-1.72$ & 0.582 \\
Family support & 0.87 & $0.23-3.27$ & 0.837 & 0.48 & $0.14-1.59$ & 0.229 \\
Spirituality & 5.84 & $1.77-19.23$ & $0.004 *$ & 2.42 & $0.83-1.59$ & 0.106 \\
Life satisfaction & 9.71 & $2.04-46.26$ & $0.004 *$ & 7.52 & $1.70-33.25$ & $0.008^{*}$ \\
*Significant at $<0.05$ & & & & & &
\end{tabular}




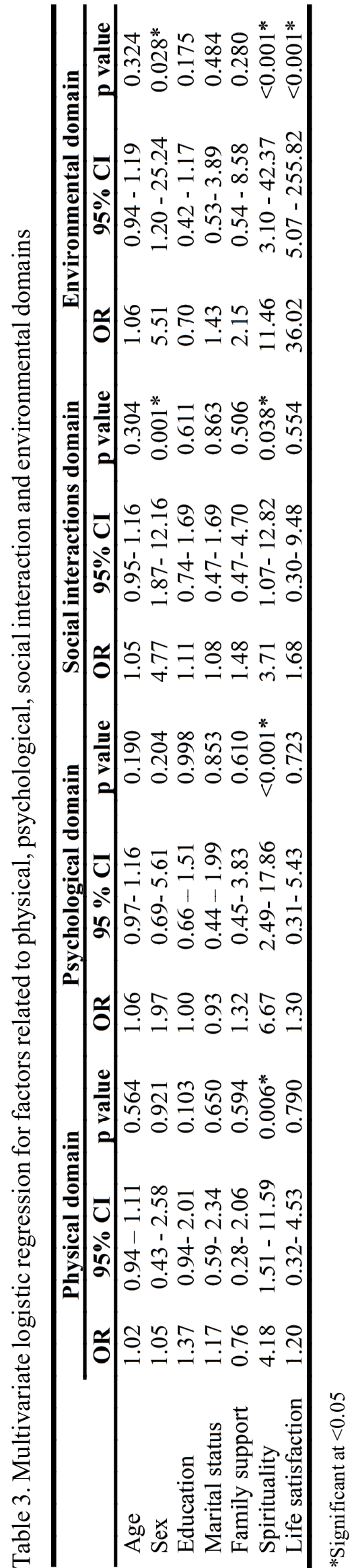

than men. Gobbens and Van Assen ${ }^{(29)}$ showed that social participation was higher in women than in men. In a study from the National Health and Nutrition Examination Survey, women also scored higher on social functioning. Social interaction was considered to be one of the most important factors of quality of life in older adults. ${ }^{(28)}$ Onunkwor et al. ${ }^{(26)}$ stated that women had a significantly lower quality of life in all domains than men. This may be because women perceived aging more negatively than men. Feelings of unattractiveness among older women could lead to low self-esteem and contribute to the negative perception of aging, resulting in a lower quality of life. ${ }^{(30)}$

Family support had no significant association with the four domains of quality of life, and both overall quality of life and general health in this study, which was contrary to previous research done in Surakarta, Central Java, where a better quality of life was found in the elderly with strong family support. ${ }^{(31)}$ A Spanish study showed that family support is as important for health as social contacts, which are a true welfare factor, and can be considered an estimate of quality of life. ${ }^{(32)}$

Spirituality showed a significant association with the overall quality of life. Spirituality was also a risk factor for physical domain, psychological domain, and environmental domain. Low spiritual level was also a risk factor for poor quality of life. This result was parallel to a research conducted by Gonzales-Celis et al., ${ }^{(6)}$ who stated that spirituality had the highest impact and had a significant association with the quality of life. Spirituality is associated with better outcomes of quality of life and has been identified as an important dimension of quality of life. ${ }^{(33,34)}$ It was found that people with high spiritual level had a higher quality of life compared to those with low spiritual level. ${ }^{(34)}$ Some studies indicated that spirituality has great relationship with an individual's health. Therefore, religion and spirituality are considered to be significant sources for compatibility with life's stressful events. Beside that, it also provides the elderly inscribable equanimity and joy. ${ }^{(35)}$ 
Life satisfaction showed a positive association with the overall quality of life and general health, as well as with the environmental domain. Low life satisfaction was found to be a risk factor for bad overall quality of life, general health, and environmental domain. A similar result was obtained in a study by Lucas-Carrasco et al. ${ }^{(36)}$ where life satisfaction was found to affect the overall quality of life, general health, and all four domains. Life satisfaction is a multidimensional concept that includes physical health, mental health, socio-economic status, social and family relationships, and the environment, that can be used to predict the mortality and morbidity of the elderly. ${ }^{(11)}$ A research in Turkey found a positive relationship between life satisfaction and quality of life. It also stated that life satisfaction will increase along with the improvement of an individual's quality of life. ${ }^{(37)}$ A correlational analysis done by Boylu and Günay ${ }^{(22)}$ showed that quality of life tends to decrease as the age increases, however it increases along with high education, good physical health, and high life satisfaction. A previous study by Indrayani et al. ${ }^{(38)}$ showed that family support was the most dominant factor related to the quality of life. In our study, we found that family support had no significant association with quality of life. In contrast, spirituality and life satisfaction are significantly associated with the overall quality of life, general health, and the four domains of quality of life.

There are three limitations in this study. First, the study was performed in only one communitybased home care center (PUSAKA), making the generalizability of the findings questionable. Second, the respondents were interviewed simultaneously. This could have made them feel uncomfortable to be straightforward about their personal matters. Thus, it might have affected the results of the interview. Third, there might also be a recall bias due to the use of self-report data. Psychological and social functions decrease, and chronic degenerative diseases increase as people age. Therefore, knowing the factors that expose the older adults to physical and emotional vulnerability is essential to provide healthy aging and palliative care for geriatric patients. Consequently, future research using a more heterogeneous elderly population is advisable. It is better if the research can be developed into a longitudinal study so that related data can be seen more clearly and better results can be obtained.

\section{CONCLUSIONS}

Life satisfaction was the most significant determinant in improving the overall quality of life and general health, as well as environmental domain of quality of life. Older people with high spiritual level and life satisfaction had a more excellent quality of life.

\section{CONFLICT OF INTEREST}

Competing interests: No relevant disclosures.

\section{ACKNOWLEDGEMENT}

The authors would like to thank all the staff of PUSAKA Meruya Ilir, who have permitted and helped this research, and all the elderly that were willing to participate in this research.

\section{CONTRIBUTORS}

All authors will take public responsibility for the content of the manuscript submitted to Universa Medicina. YSH and TV contributed to the study concept and design of the study. YSH and TV contributed to drafting the manuscript. YSH contributed to the critical revision of the manuscript. All authors have read and approved the final manuscript.

\section{REFERENCES}

1. Pusat Data dan Informasi Kementerian Kesehatan Republik Indonesia. Analisis lansia di Indonesia 2017. Jakarta: Pusat Data dan Informasi Kementerian Kesehatan Republik Indonesia; 2017. 
2. Badan Pusat Statistik. Statistik Penduduk Lanjut Usia 2018. Jakarta: Badan Pusat Statistik; 2018.

3. Khaje-Bishak Y, Payahoo L, Pourghasem B, Asghari Jafarabadi M. Assessing the quality of life in elderly people and related factors in Tabriz, Iran. J Caring Sci 2014 1;3:257-63. doi:10.5681/ jcs.2014.028.

4. Kaur H, Kaur H, Venkateashan M. Factors determining family support and quality of life of elderly population. Int J Med Sci Public Health 2015;4:1049. doi:10.5455/ijmsph.2015. 21012015220.

5. Gräske J, Meyer S, Worch A, Wolf-Ostermann K. Family visits in shared-housing arrangements for residents with dementia - a cross-sectional study on the impact on residents' quality of life. BMC Geriatrics 2015; 15:9. doi: 10.1186/s12877-015-00125.

6. González-Celis AL, Gómez-Benito J. Spirituality and quality of life and its effect on depression in older adults in Mexico. Psychology 2013;04:17882. doi: 10.4236/psych.2013.43027.

7. Cowlishaw S, Niele S, Teshuva K, Browning C, Kendig H. Older adults' spirituality and life satisfaction: a longitudinal test of social support and sense of coherence as mediating mechanisms. Ageing Society 2013;33:1243-62. doi: 10.1017/S0144686X12000633.

8. Farajzadeh M, Ghanei Gheshlagh R, Sayehmiri K. Health related quality of life in Iranian elderly citizens: a systematic review and meta-analysis. Int J Commun Based Nurs Midwifery 2017;5:100 11.

9. Poor HJ, Borji M, Borji M, Moslemi A. The relationship between spiritual well-being and quality of life and optimism on the staff of Arak University of Medical Science. Health Spiritual Med Ethics 2016;3:8-15.

10. Jafaripoor H, Safarabadi M, Pourandish Y, et al. The elders' spiritual well-being and their quality of life: a cross-sectional study. J Client-Centered Nurs Care 2019;30;145-54.

11. Lim HJ, Min DK, Thorpe L, Lee CH. Multidimensional construct of life satisfaction in older adults in Korea: a six-year follow-up study. BMC Geriatrics 2016;16:197. doi: 10.1186/s12877016-0369-0.

12. Kiarsipour N, Borhani F, Esmaeili R, Zayeri F. The correlation of aging perceptions and life satisfaction in Iranian older adults. Ann Trop Med Public Health 2017;10:861-8.

13. Karner-Hutuleac A. Quality of life and spirituality. Eur J Sci Theol 2012;8:135-41

14. Bakar N, Asilar RH. Factors affecting depression and quality of life in the elderly. J Gerontol Geriatr Res 2015;04:8. doi:10.4172/2167-7182.1000249.
15. Salim OC, Sudharma NI, Kusumaratna RK, Hidayat A. Validitas dan reliabilitas WHOQOLBREF untuk mengukur kualitas hidup lanjut usia. Univ Med 2016;26: 27-38. DOI: http://dx.doi.org/ 10.18051/UnivMed.2007.v26.27-38.

16. Soósová MS, Mauer B. Psychometrics properties of the daily spiritual experience scale in Slovak elderly. J Relig Health 2020;59. doi:10.1007/s10943020-00994-w.

17. Underwood LG. The daily spiritual experience scale: overview and results. Religions 2011;2:2950. doi:10.3390/rel2010029.

18. Loustalot F, Wyatt SB, Sims M, Ellison CG, Taylor HA, Underwood L. Psychometric testing of the daily spiritual experiences scale among African Americans in the Jackson Heart Study. J Relig Health 2011;50:675-85. doi:10.1007/s10943-0099278-2.

19. Tselebis A, Anagnostopoulou T, Bratis D, et al. The 13 item family support scale: reliability and validity of the Greek translation in a sample of Greek health care professionals. Asia Pac Fam Med 2011;10:3. https://doi.org/10.1186/1447056X-10-3.

20. Bratis D, Tselebis A, Sikaras C, et al. Alexithymia and its association with burnout, depression and family support among Greek nursing staff. Hum Resour Health 2009;7:6. doi:10.1186/1478-4491-772.

21. Diener E, Emmons RA, Larsen RJ, Griffin S. The satisfaction with life scale. J Pers Assess 2010;49: 71-5. https://doi.org/10.1207/s15327752jpa4901_ 13.

22. Boylu AA, Günay G. Life satisfaction and quality of life among the elderly: moderating effect of activities of daily living. Turkish J Geriatr 2017;20: 61-9.

23. Galanakis M, Lakioti A, Pezirkianidis C, Karakasidou E. Reliability and validity of the satisfaction with life scale (SWLS) in a Greek sample. Int J Humanit Soc Stud 2017;5:9.

24. Silva PAB, Soares SM, Santos JFG, Silva LB. Cutoff point for WHOQOL-BREF as a measure of quality of life of older adults. Rev Saúde Pública 2014;48:390-7.

25. Ranganathan P, Pramesh CS, Aggarwal R. Common pitfalls in statistical analysis: logistic regression. Perspect Clin Res 2017;8:148-51. doi: 10.4103/picr.PICR_87_17.

26. Onunkwor OF, Al-Dubai SAR, George PP, et al. A cross-sectional study on quality of life among the elderly in non-governmental organizations' elderly homes in Kuala Lumpur. Health Qual Life Outcomes 2016;14:10. doi: 10.1186/s12955-0160408-8. 
27. Campos ACV, Ferreira EF, Vargas AMD, Albala C Aging, gender and quality of life (AGEQOL) study: factors associated with good quality of life in older Brazilian community-dwelling adults. Health Qual Life Outcomes 2014;12:11. doi: 10.1186/s12955-014-0166-4.

28. Gobbens RJ, Remmen R. The effects of sociodemographic factors on quality of life among people aged 50 years or older are not unequivocal: comparing SF-12, WHOQOL-BREF, and WHOQOL-OLD. Clin Interv Aging 2019; 14: 231-9. doi: 10.2147/CIA.S189560.

29. Gobbens RJ, van Assen MALM. Associations between multidimensional frailty and quality of life among Dutch older people. Arch Gerontol Geriatr 2017;73:69-76.DOI: 10.1016/j.archger.2017. 07.007.

30. Sabik NJ. Ageism and body esteem: associations with psychological well-being among late middleaged African American and European American women. J Gerontol B Psychol Sci Soc Sci 2015;70: 189-99. doi: 10.1093/geronb/gbt080. doi: 10.1093/ geronb/gbt080.

31. Suwarni S, Soemanto RB, Sudiyanto A. Effect of dementia, family support, peer support, type of residence, and marital status on quality of life of the elderly in Surakarta, Central Java. J Epidemiol Public Health 2018;3:83-94.

32. García LMR, Navarrro JMR. The impact of quality of life on the health of older people from a multidimensional perspective. J Aging Res 2018; 2018:7. DOI: https://doi.org/10.1155/2018/4086294.
33. Counted V, Possamai A, Meade T. Relational spirituality and quality of life 2007 to 2017: an integrative research review. Health Qual Life Outcomes 2018;16:18. doi:10.1186/s12955-0180895-x.

34. Panzini RG, Mosqueiro BP, Zimpel RR, Bandeira DR, Rocha NS, Fleck MP. Quality-of-life and spirituality. Int Rev Psychiatr 2017;29:263-82. DOI: http://dx.doi.org/10.1080/09540261.2017.1285553.

35. Seraji M, Shojaezade D, Rakhshani F. The relationship between spiritual well-being and quality of life among the elderly people residing in Zahedan city (South-East of Iran). Elderly Health J 2016;2:84-8.

36. Lucas-Carrasco R, Den Oudsten BL, Eser E, Power MJ. Using the satisfaction with life scale in people with Parkinson's disease: a validation study in different European countries. Sci World J 2014; Article ID 680659. doi:10.1155/2014/680659.

37. Yildirim Y, Kilic SP, Akyol AD. Relationship between life satisfaction and quality of life in Turkish nursing school students: nursing student quality of life. Nursing Health Sci 2013;15:41522.

38. Indrayani I, Ronoatmodjo S. Faktor-faktor yang berhubungan dengan kualitas hidup lansia di desa Cipasung kabupaten Kuningan tahun 2017. J Kesehat Reprod 2018;9:1-10. DOI: https:// doi.org/10.22435/kespro.v9i1.892.69-78. 